\title{
AN ANALYSIS OF ENGLISH TEACHER AND LEARNER TALK IN THE CLASSROOM INTERACTION
}

\author{
Shofiyatul Huriyah ${ }^{1}$ \\ UNIVERSITAS BATURAJA \\ Merie Agustiani ${ }^{2}$ \\ UNIVERSITAS BATURAJA \\ merieagustiani@gmail.com ${ }^{1}$
}

Submit, 22-10-2018 Accepted, 22-12-2018 Publish, 22-12-2018

\begin{abstract}
The objectives of the research were to find out the kinds of teacher talk and learner talk used by English teacherand learners during the classroom interaction and to know the language mostly used in the classroom. The participants of this study were 35 students and 1 English teacher that were taken using purposive sampling technique. This descriptive study used recording and interview in colecting the data. The results of clasroom interaction recording was then analyzed using Flander's Interaction Analysis Categories (FIAC). It was obtained that teacher talk $(75,5 \%)$ dominated the interaction during the classroom. In the interaction, the teacher mostly used ask question category $(30,2 \%)$ meanwhile the learners mostly used pupil talk response category $(9,1 \%)$. Furthermore, Indonesian language $(57,2 \%)$ was dominantly used, while English was only $28,1 \%$. From the research result, it can be concluded that the English teacher dominated the class by asking so many questions and mostly used Indonesian language during the classroom was taking place. It gave the students less chance to explore and practice their English.
\end{abstract}

Keyword: teacher talk, learner talk, classroom interaction.

\section{INTRODUCTION}

Harmer (2007:56) describes that there are three phases of successful language learning which is well known as ESA phases; Engage (E), Study (S), and Activate (A). Engagebecomes the first important key before encouraging the students to study and practice. It is necessary to engage the students in order to get them interested in the subject. Therefore, good interaction between teacher and students will help the teachers to create good rapport).Teacher-students interaction supports and motivates students to achieve a higher cognitive level and to find a 
personal meaning for learning (Dempsey, Halton, \& Murphy, 2001). In addition, Sundari (2017) through her qualitative research entitled classroom interaction in TEFL at Lower secondary Schools in Indonesia described that mostly classroom interaction should be initiated by teachers through verbal communication by combining first and target language, giving direction, asking questions, correcting the students' errors and many more. Verbal and non verbal dimension, pedagogical, and personal dimensions arise the head to control and manage the classroomand to build rapport between teacher and students.

Interaction is one essential point of prosperous in teaching learning process, because interaction is a united exchange of thought, feeling or ideas between a teacher and learner or a learner and other learner consequent in complementary effect on each other. Thus, Brock (in Shomoosi, 2008:177) states that an increase in the amount of classroom interaction will help foreign language learner to learn the target language easily and quickly. In this case, teaching process indeed gives a opportunity for learners to ask, to guess, to think and even to talk about the course material orderly to create an interaction between students. In the classroom interaction, it contain all of the classroom events, both verbal and non verbal interaction, the verbal interaction transpired because of the teacher and learners talk, while non verbal interaction covered gestures or facial expression by the teacher and learners when they communicate without using words (Sukarmi \& Ulfah, 2015:262).

From the statements above, the two kinds of talk are important, they prevail the classroom events and affect students' foreign language acquisition,learners learn not only straight comprehensible input but also their own output (Sukarmi \& Ulfah, 2015:262). But a proper lesson was not one in which students do all or even most of the talking. Some lesson may propered if they were carefully organized in such away that students did a good arrangement of talking and at the same time got a lot of feedback from the teacher, either formally and informally.

Classroom interaction was basically related to teaching style that determines interaction in the classroom. The teachers who apply teacher-centered in the classroom possibly make the students passive in the classroom since the teacher talks all the time. It simply meant that the teachers did not give chance to the students to talk. In contrast, students-centered indirectly made the students active since the teacher was as a facilitator. So, it was clear that to get better result on teaching English especially in Senior High School had to be developed by improving the quality of the teacher and learner talk because they would govern the classroom behavior. Moreover, while the teaching-learning occurs, interaction was foremost it, avoid the blank moment during teaching learning process, both 
teacher and learners there must be interaction, both of them should be active in the classroom.

The importance of verbal interaction in language classroom made some researchers were interested in analyzing some kinds of teacher talks that occured during the classroom was taking place with many foreign language interaction analysis models. Some of those models are Foreign Language Interaction (FLINT), Flanders' Interaction Categories (FIAC), Self-Evaluation Teacher Talk (SETT). Pangesti (2016:34) conducted an analysis of teacher talk in English teaching and learning process using FLINT models. It was found that there were 9 out of 11 categories of teacher talks occured in the class. They were praising, making jokes, using the students' ideas, repeating the students' responses, asking question, giving information, correcting without rejection, giving directions, and criticizing students' behaviour. Wasi'ah (2016:78) that conducted a descriptive study on analysing teacher talk using SETT found that teacher performed 11 out of 14 instructional features in classroom interaction; scaffolding, direct repair, content feedback, extended wait time, seeking clarification, confirmation checks, teacher echo, teacher interruption, extended teacher turn, extended learner turn and display question.

The other guidelines to analyze the interaction activities is by using Flanders' Interaction Analysis Categories FIAC. Amatari (2015:44) states there are three categories inFIAC, they are: teacher talk, pupil talk and silence or confusion. Teacher talk includes accept feeling, praises, accept/ uses ideas of pupil, ask question, lecturing, giving direction and criticizing, student talk includes pupil talk response, pupil talk initiation and no/all talk is the situation which is in silence.Sukarmi and Ulfah (2015:90) who conducted the classroom inteaction analysis using this model obtained thatthe percentage of the teacher talk was $78.15 \%$,whereas the students' participation was $21.16 \%$.

In line with the studies above, this present study was also dealing with analysing the student and the teacher talk in English classroom interaction through FIAC.Not only finding the dominant categories of teacher and learner talk, this study also investigated the language that mostly used in the classroom. As Setiawati (2012:78) stated that teacher talk serves as the most valuable input of language exposure due to the circumstance in Indonesia that does not support students' to use target language in daily conversation. So it is very expected that teacher used English more frequently in the classroom to become comprehensible input for students. 


\section{LITERATURE REVIEW}

\section{Classroom Interaction}

Yanfen and Yuqin (2010:67) defines interaction as the collaborative exchange of thoughts, feelings or ideas between two or more people. It has an inportant role in English language teaching. Through interaction with teachers, students can increase their language store and use the language the possess. Amatari (2015:45) points out that the quality and quantity of teacher-student interaction is a critical dimension of effective classroom teaching. The term 'interaction' implies an action - reaction or a mutual or reciprocal influence which may be between individuals, e.g. pupil - pupil; teacher-pupil in classroom setting or between materials and individuals or groups. An interaction is usually inferred from the behaviour of persons in the environment being studied. This behaviour maybe verbal or non-verbal and can be classified as being predominantly cognitive, affective or controlling in nature

The success of teaching depends to a large extent on the way of teacher talk and the interaction occurs between teacher and students. The happening of interaction is affected directly by the way teacher talk. Classroom interaction is really needed to maintain communication to happen in the classroom. Ellis (1984:78) points out that interaction is meaning-focused and carried out to facilitate the information exchange and avoid the breakdowns of communication. So it is very suggested that teachers should pay attention to their language in the process of interaction with students, so as to provoke more interactionsin the classroom.

\section{Teacher and Leaner Talk}

Talk can be defined as an instrument to change attitudes and produce decisions and actions. Talk laso can be defined as means of learning, transferring meaning, tool of reflection and making sense, and also social purpose.. In terms of classroom environment, teacher and learner talk can be defined as the language used by the teacher and learnersa to interact with in classroom interaction.

Sinclair and Brazil (in Yanfen and Yuqin, 2010:56) explain that teacher talk is the language in the classroom that takes up a major portion of class time employed to give directions, explain activities and check students' understanding. Nunan (2000:23) describes that in all types of classrooms. Teacher talk is important, and it has been extensively researched and documented. In language classroom, it is particularly important because the medium is message. The modifications which teachers make to their language, the question they ask, the feedback they provide and the types of instruction and explanations they provide 
can all have an important bearing, not only on the effective management of the classroom, but also the on the acquisition by the learners of the target language.

Lei (2009:67) explains that teacher talk in EFL classroom was considered to be problematic are for language teachers. In one side, too much teacher talk will deprive students' opportunity to speak in the classroom. But in another side, teacher talk can be effectively facilitate learning and promote communicative interaction in the classroom.

However, Nunan (2000:90) suggests that when determining the appropriateness or otherwise of the quantity of teacher talk, then, we need to take into account a variety of factors including: (1) the point in the lesson in which the talking occurs, (2) what prompts the teacher talk: whether it is spontaneous or planned, (3) the value of the talk as potentially useful input for acquisition.

\section{Flanders Interaction Analysis Categories (FIAC)}

Inamullah, Uddin, and Husain (2008:34) tells that Flanders Interaction (FIAC) is one of analytical observation schemes that became a widely used coding system to analyze and improve teaching skills. In addition, Amatari (2015:98) points out that Flanders Interaction Analysis is a system of classroom interaction analysis which is concerned with verbal behaviour only, primarily because it can be observed with higher reliability than can non-verbal behaviour and more also, the assumption made that the verbal behaviour of an individual is an adequate sample of his total behaviour. Flanders Interaction Analysis Categories (FIAC) is a Ten Category System of communication which are said to be inclusive of all communication possibilities. There are seven categories used when the teacher is talking (Teacher talk) and two when the pupil is talking (Pupil talk) and tenth category is that of silence or confusion.

\section{RESEARCH METHOD}

In conducting this study the researchers applied descriptive method. Descriptive method means that the researcher describes which is described and interpretesthe phenomenon or condition (Creswell, 2012:13). This study took place in SMA Negeri 5 OKU. Purposive sampling wasused to determine the particpants of the study. On the basis of school's recomendation, Irma Purwati, S.Pd and students in XI IPA 2 would participated in the study.

In collecting the data, classroom observation and interview were employed in the study.Cohen, Manion and Morrison (2007:396) explain that observation as a research process is that it offers an investigator the opportunity to gather data from naturally occurring social situations. The observation in this study was conducted twice and last took eighty to ninety five minutes, The researchers directly observed the classroom. In the meantime, audio/ video recording of the 
whole proceeding was also made to acquire more complete data about the classroom process. Steps of this research procedure were: (1) recording and observing all of the classroom activities, (2) making a transcript of recording in every minutes lecturing, (3) determining the early data from field notes \& transcript, (4) categorizing the data, (5) determining the focus of data categorization, (6) strengthening the focus of data categorization, (7) formulating flanders theory by using tables, (8) making a count of the numbers of language used by using table.

The data in this research were in the form of utterances taken from the data resources (field notes \& transcription) then were analyzed using FIAC system and calculated into the numbers and percentage analysis.

Furthermore, In this research, the researchers used guided interview to give some questions to collect more suplementary data about teacher and learner talk in the classroom interaction.Cohen, Manion and Morrison (2007:349) state that the interview is a flexible tool for data collection, enabling multi-sensory channels to use: verbal, non-verbal, spoken and heard. The order of the interview may be controlled while still giving space for spontaneity, and the interviewer could pressed not only for complete answers but also for responses about complex and deep issues. In short, the interview was a powerful implement for researchers. The questions were administered in Bahasa Indonesia, because it made the interview more easily both for the teacher and the students.

\section{FINDING}

The classroom interaction was observed in 80 minutes length for only one meeting because of the school limitation. The observed behavior was translated into the descriptive codes. Its printed out was enclosed in appendix. The data was Analysis resulted in a table of calculating data on classroom interaction, the table was calculated from every utterances of teacher and learner that occured in the clasroom.Table 1 showed the result of FIAC calculation after the classroom interaction was transcripted.

Table 1 The Result of FIAC Calculation

\begin{tabular}{ccccccccccc}
\hline CATEGORIES & $\mathbf{1}$ & $\mathbf{2}$ & $\mathbf{3}$ & $\mathbf{4}$ & $\mathbf{5}$ & $\mathbf{6}$ & $\mathbf{7}$ & $\mathbf{8}$ & $\mathbf{9}$ & $\mathbf{1 0}$ \\
& & & & & & & & & & \\
\cline { 2 - 9 } & I & IIIII & III & IIIII & IIIII & IIIII & IIIII & IIIII & IIII & IIIII \\
\hline & & IIIII & & IIIII & IIIII & IIIII & IIIII & IIIII & & IIIII \\
\hline & & III & IIIII & IIIII & IIIII & I & IIIII & IIIII \\
\hline & & & IIIII & IIIII & IIIII & & IIIII & IIIII \\
\hline
\end{tabular}




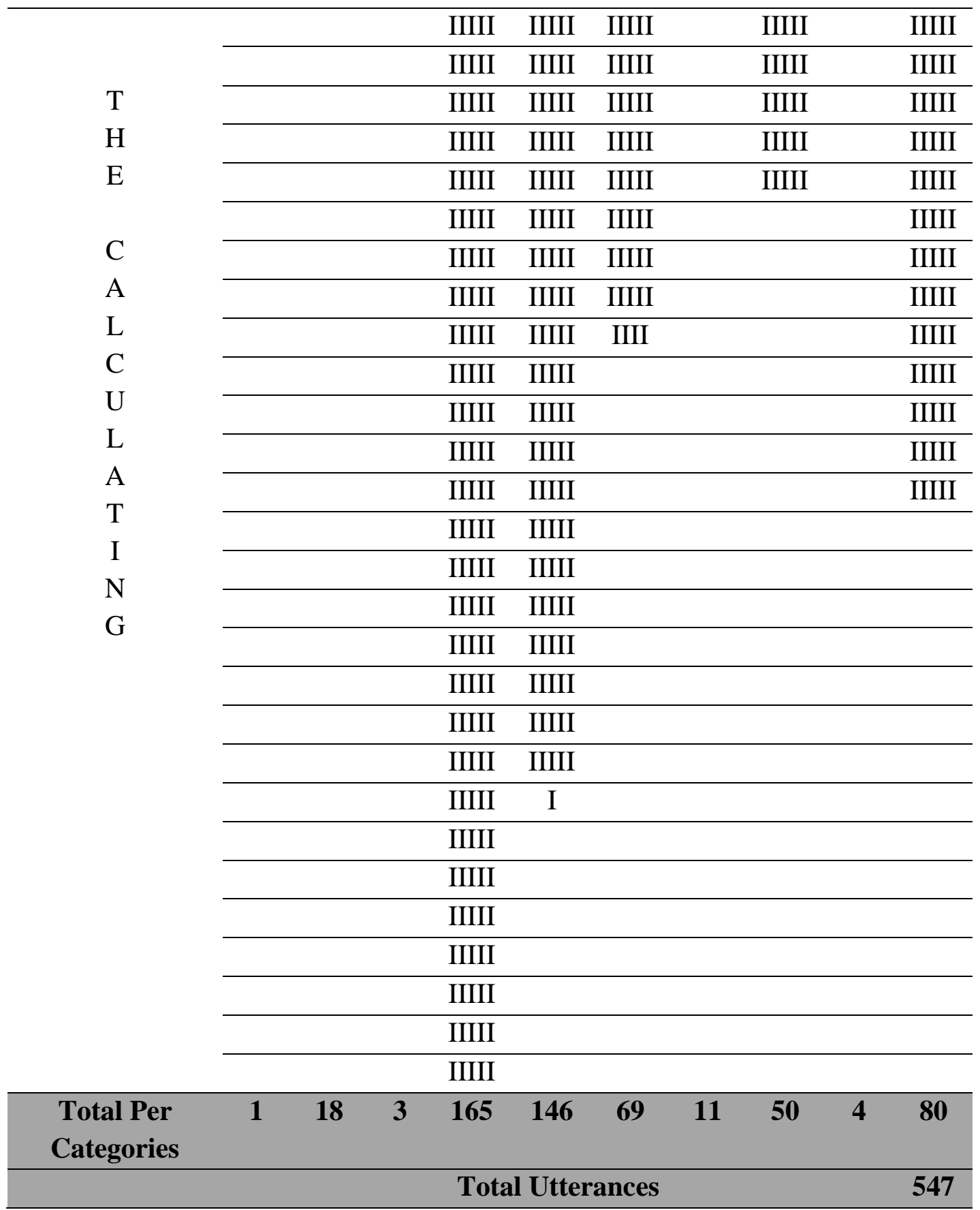

Note:

1. Accepts feeling

2. Praises or encourages

3. Accepts or uses ideas of pupil

4. Asks question

5. Lecturing
6. Giving Direction

7. Criticizing

8. Pupil talk response

9. Pupil talk initiation

10. Silence or confusion 
From the result of transcription of the recording during the classroom observation, it was obtained that there were 413 utterances of teacher talk and 134 utterances of learner talks. These result then analyzed calculated usingFIAC. The result of percentage based on the data result of classroom observation was shown in table 2

Table 2 The Distribution of Classroom Observation using FIAC

\begin{tabular}{|c|c|c|c|}
\hline No & Observation Categories & Numbers & $\%$ \\
\hline \multicolumn{4}{|c|}{ Teacher' Talks } \\
\hline 1 & Accept feeling & 1 & $0,2 \%$ \\
\hline 2 & Praises or encourages & 18 & $3,4 \%$ \\
\hline 3 & Accepts or uses ideas of pupil & 3 & $0,5 \%$ \\
\hline 4 & Asks questions & 165 & $30,4 \%$ \\
\hline 5 & Lecturing & 146 & $26,7 \%$ \\
\hline 6 & Giving directions & 69 & $12,6 \%$ \\
\hline 7 & Criticizing & 11 & $2,0 \%$ \\
\hline \multicolumn{3}{|c|}{ Total } & $75,6 \%$ \\
\hline \multicolumn{4}{|c|}{ Learners' talk } \\
\hline 8 & Pupil talk response & 50 & $9,1 \%$ \\
\hline 9 & Pupil talk initiation & 4 & $0,7 \%$ \\
\hline 10 & Silance or confusion & 80 & $14,6 \%$ \\
\hline \multicolumn{3}{|c|}{$\begin{array}{l}\text { Total } \\
\end{array}$} & $24,4 \%$ \\
\hline
\end{tabular}

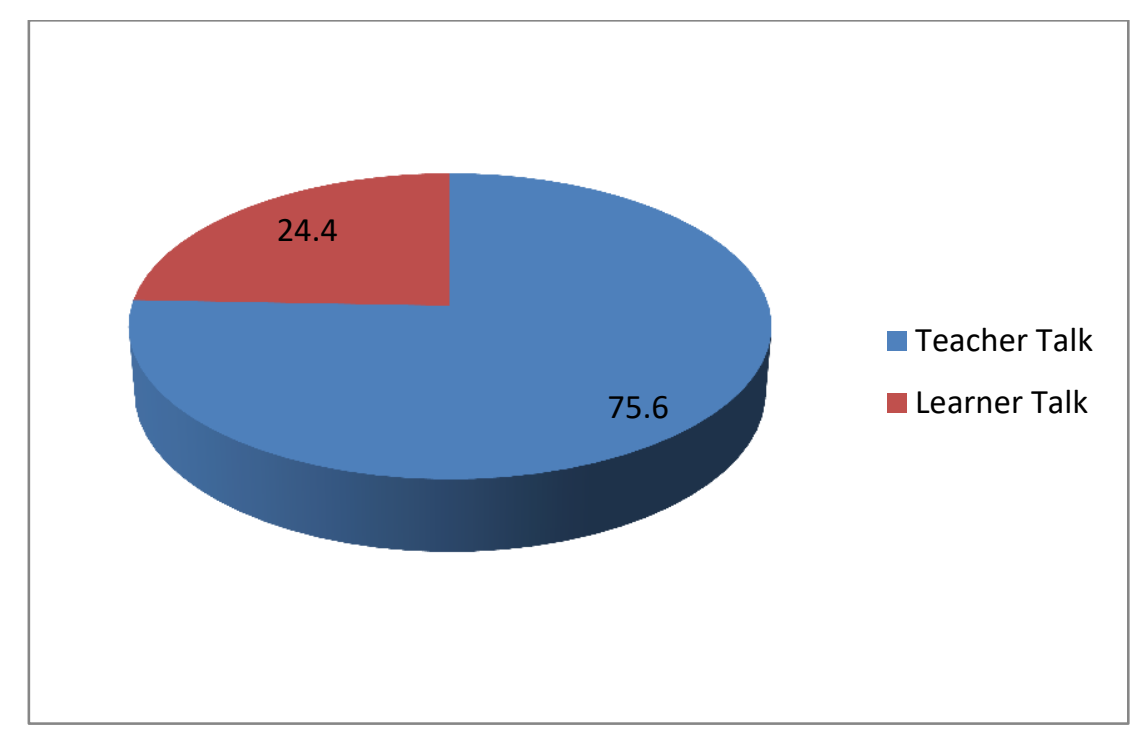

Diagram 1. The Percentage Result of Teacher and Learner Talks 
From the overall result of observation displayed in the research found that the most time-spend of teacher and student talk in the classroom interaction was the teacher talk which occupied $75,5 \%$ of time, whereas the learner talk occupied $9,8 \%$. The rest $14,6 \%$ of the time was that of silence, confusion or unclassified talk. It can also be seen that from the whole time of teacher talk,it was mostly spent for asking questions, lecturing and giving directions, while most of students talk was for giving responses.

The result of study showed that the teacher talk was $75,5 \%$, students talk was $9,8 \%$, and silent was $14,6 \%$ of the time. Only a small part of the student talk shows initiation related to the learning materials. Instead, they talked a lot when they gave responsesto that teacher's lecture or questions. The teacher was more direct in her teaching. It can be seen from the ratio between direct and indirect influence, the result is less than one. It meant the teacher give lessons (lecturing) and direction during the teaching learning process. The teacher attemps to make her student being more active in the class by giving them chance to ask when the teacher was lecturing.

Furthermore, the result of classroom observation found 154 utterancesof using the English and 313 utterances of using the Indonesian or local language. This tables on show the percentages of the language use based on research founding on classroom observation.

Table 3 The Distribution of Language Use based on the Cclassroom Observation

\begin{tabular}{lccc}
\hline \multirow{2}{*}{ Language } & Speakers & \multicolumn{2}{c}{ Observation } \\
& Teacher & 113 & $20,6 \%$ \\
\multirow{2}{*}{ English } & Students & 41 & $7,5 \%$ \\
& Total & $\mathbf{1 5 4}$ & $\mathbf{2 8 , 1} \%$ \\
\hline \multirow{3}{*}{ Indonesian } & Teacher & 293 & $53,6 \%$ \\
& Students & 20 & $3,6 \%$ \\
& Total & $\mathbf{3 1 3}$ & $\mathbf{5 7 , 2} \%$ \\
\hline
\end{tabular}




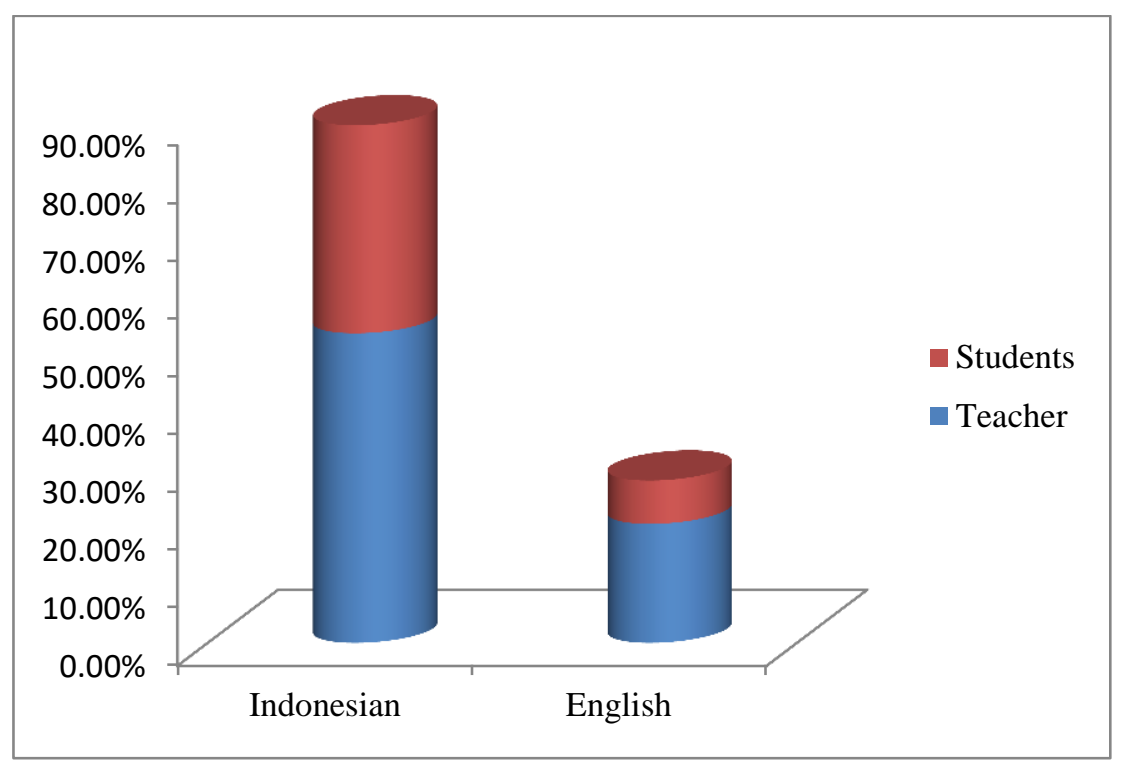

Diagram 2. Percentage Analysis of Language Use

From the table 3, we could see the English teacher often used Indonesianor local language than English. The teacher used Indonesian or local language about $53,6 \%$, and English used only about 20,6 \%. Meanwhile, students often used English than Indonesian or local language, the students used English about $7.5 \%$, and the indonesian only about $3,6 \%$.

\section{DISCUSSION}

The finding of this study was in line with Sukarmi and Ulfah $(2015: 23)$ who found that the teacher talk' percentage in the classroom was $78.15 \%$ with dominant categories were lecturing 921.63\%) and giving direction (20\%). Almost similar with Sukarmi and Ulfa's, this result was seen as less effective teaching and learning proces seen the dominant categories were asking questions $(30.4 \%)$ and lecturing (26.7\%). Negative effects of teacher talking for an excessive amount of time have been observed in a number of studies. Alwright (in Davies 2011:98) claimed that teacher who works to much in the classroom were not teaching effectively. A good language teacher should be able to get the students to do more works in the classroom. Hammer (2007:76) also described that Student talking Time (STT) should be more frequently than Teacher Talking Time (TTT). It is beacause the greater amount of TTT, the less the students practice the target language. Teachers and learners are together contributing source in managing the classroom interaction and at the same time managing the learning opportunities. The teacher as facilitator should focus on the principle of intrinsic motivation by 
allowing the students to discover language through using it rather than telling them about language (Choudhury,2005:65).

The frequent use of L1 that was obtained from this study showed that the teacher did not optimize the use of English in her classroom which can reduce the exposure of the target language. Ellis (1984:45) states that too much L1 use could deprive the learners of valuable input in the L2. Although some related studies results inferred that learners' L1 has a necessary and facilitating role in acquiring a foreign language under certain conditions (Cinkara and Galali, 2017:56).Harmer (2007:89) explains thatthe teachers should be aware of monitoring the appropriate use of first language in English classroom, so that it can optimalize the target language learning.

\section{CONCLUSION}

Based on the result of this research, it can be concluded the teacher dominated the class. The teacher was more active while the students were less actice. The student talking time was used largely for responding to the teacher's questions and lecture.The teacher used direct influence more in teaching her student than indirect influence; lecturing and giving direction to the students for teaching learning process. In addition, the language in classroom used by the teacher and the students in the classroom interaction did not balance between Indonesian and English. It showed that the teacher used more Indonesian than English when she explained the materials.

Referring to those, it is suggested that the teacher should optimize the interaction to make the classroom more dynamic and not monotonous. The teacher were recommended to develop and improve their basic ability in managing their talk and technique in giving the appropriate questions and good feedbacks for the students in English class. So it can be expected that with all the type of the talk, the interaction between the teacher and the students will be built and increase. The teacher must be a good facilitator and motivator to the students in learning English. In addition, reagarding to the use of language inthe classroom, it is recommended that the teacher should use English more frequently in order to make students feel the athmosphere of English language and they can getthe chance to exposure the target language they are learning.

\section{REFERENCES}

Amatari, V. O. (2015). The instructional process: A review of Flanders' interaction analysis in a classroom setting. International Journal of Secondary Education, 3(5), 43-49.

Choudhury, S. (2005). Interaction insecond language classroom. BRAC University Journal, 2(1), 77-82. 
Cinkara, E. \& Galali, A. (2017). The use of L1 in English as foreign language classes: Insight from Iraqi tertiary level students.Advances in Language and Literary Studies (ALLS),8(5), 54-64.

Cohen, L.,Manion, L., \& Morrison, K. (2005).Research methods in education $\left(5^{\text {th }}\right.$ ed.). New York, USA: RoutledgeFalmer.

Creswell, J. W. (2012). Educational research: Planning, conducting, and evaluating quantitative and qualitative research ( $4^{\text {th }}$ ed.). Boston, UK: Pearson Education.

Davies, M. J. (2011). Increacing students' L2 usage: An analysis teacher talk time and students talk time. Retrieved from https://www.birmingham.ac.uk/Documents/collegeartslaw/cels/essays/languageteaching/Daviesessay1TTTessaybank.pdf

Dempsey, M., Halton, C., \& Murphy, M. (2001). Reflective learning in social work education: Scaffolding the process. Social Work Education, 20 (6), 631-641.

Ellis, R. (1984). Classroom second language development. Oxford: Pergamon.

Harmer, J. 2007. How to Teach English. London, UK: Longman.

Lei, X. (2009). Communicative teacher talk in English classroom. English Language Teaching, 2(1), 75-79.

Nunan, D. (2000). Language taeching methodology: A textbook for teachers. Edinburgh: Pearson Education Ltd

Pangesti, D. (2016). Teacher talk in English and learning process at SMA Batik 1 Surakarta. $\quad$ Retrieved from http://eprints.ums.ac.id/44202/1/PUBLICATION\%20ARTICLE.pdf

Setiawati, L. (2012). A desriptive study on the teacher talkat EYL classroom. CONAPLIN Journal, 1(2), 33-38.

Shomoosi.(2008). Classroom interaction medieted by gender and technology: The language laboratory course. Novitas Royal. 2(2). 176-184.

Sundari, H. (2017). Classroom interaction in teaching English as foreign language at lower secondary schools in Indonesia. Advances in Language and Literary Studies (ALLS), 8(6), 147-154.

Sukarmi, S., \& Ulfah, S. (2015). An analysis of teacher and student talk in the classroom interaction of the eighth grade of SmpNegeri 18 Purworejo. Journal Vision, 4(2), 161-277.

Wasi'ah, N. (2016). A study of teacher talk in classroom interaction at an Islamic Senior High School. OKARA Journal of Language and Literature, 1, 2943

Yanfen, L., and Yuqin, Z. (2010). A study of teacher talk in interactions in English classes. Chinese Journal of Applied Linguistics, 33(2), 76-86 
2018. Linguistic, English Education and Art (LEEA) Journal 2 (1):60-71 